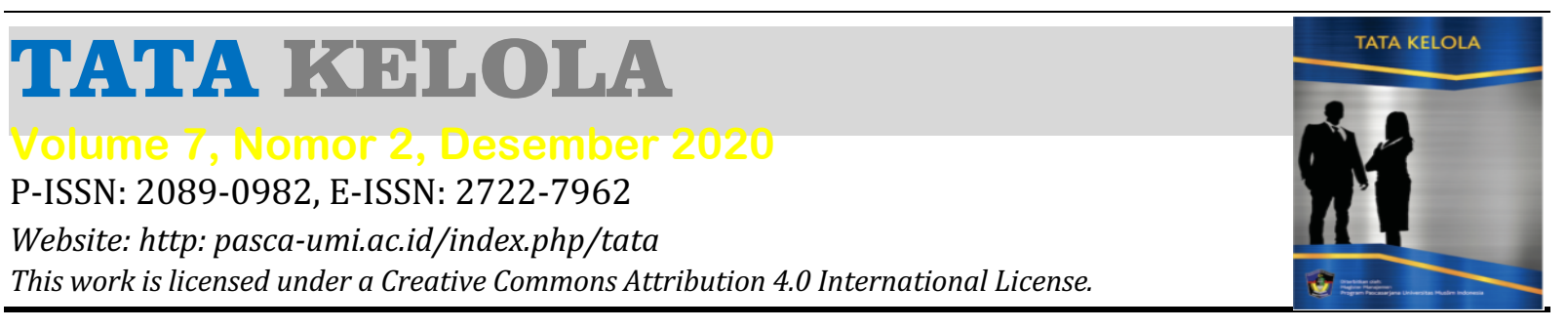

\title{
Pengaruh Kompetensi Terhadap Kinerja Pegawai Kantor Pengawasan dan Pelayanan Bea dan Cukai Tipe Madya Pabean B Makassar
}

\author{
Muchlis' ${ }^{1}$ Abdul Rahman Mus², Imaduddin ${ }^{3}$ \\ ${ }^{1,2,3}$ Magister Manajemen, Universitas Muslim Indonesia. \\ ${ }^{1}$ Koresponden Penulis, E-mail: muchlis.mus1@gmail.com
}

\begin{abstract}
ABSTRAK
Tujuan penelitian ini adalah untuk mengetahui Pengaruh Kompetensi Terhadap Kinerja Pegawai Kantor Pengawasan dan Pelayanan Bea dan Cukai Tipe Madya Pabean B Makassar yang terdiri dari pengetahuan, keterampilan, sikap kerja dan pengalaman kerja pegawai Kantor Pengawasan dan Pelayanan Bea dan Cukai Tipe Madya Pabean B Makassar dengan jumlah sampel sebanyak 112 orang. Metode dalam pengumpulan data dalam penelitian ini adalah kuesioner, wawancara, dan dokumentasi. Metode analisis data menggunakan metode deskriptif dan metode kuantitatif yaitu dengan analisis regresi linear berganda. Berdasarkan uji $F$ variabel bebas (pengetahuan, keterampilan, sikap kerja dan pengalaman kerja) secara bersama-sama memilki pengaruh yang positif dan signifikan terhadap variabel terikat (kinerja pegawai). Melalui pengujian koefisien korelasi $(R)$ diperoleh bahwa tingkat korelasi atau hubungan antara kompetensi (pengetahuan, keterampilan, sikap kerja danpPengalaman kerja) terhadap kinerja pegawai merupakan hubungan yang tinggi yaitu $86.5 \%$ dan sikap kerja merupakan faktor yang paling dominan mempengaruhi kinerja pegawai Kantor Pengawasan dan Pelayanan Bea dan Cukai Tipe Madya Pabean B Makassar.
\end{abstract}

Kata Kunci: Kompetensi; Kinerja Pegawai; Pengawasan; Pelayanan, Bea \& Cukai

\begin{abstract}
The purpose of this research is to know the influence of Employee Performance Against Competencies at the Supervision and Service Office (KPPBC) Type of B Customs Madya Makassar that consists of knowledge, skills, attitude and experience of work employees at the Supervision and Service Office (KPPBC) Type of B Customs Madya Makassar with number of samples as much as 112 people. Method of data collection in this study is a questionnaire, interviews and documentation. Methods of data analysis using the method of descriptive and quantitative methods with multiple linear regression. Based on a test of the free variable $F$ (knowledge, skills, attitudes and work experience) together have a positive and significant influence against a variable is bound (the performance of the employee). Through testing $(R)$ correlation coefficient obtained that level of correlation or relationship between Competencies (knowledge, skills, attitudes and work experience) against the performance of the employees is a high relationship i.e., $86.5 \%$ and work attitude is the most dominant factor influencing the performance of Employees at the Supervision and Service Office (КРPBC) Type of B Customs Madya Makassar.
\end{abstract}

Keywords: Competence; Employee Performance; Supervision; Services, Customs \& Excise 


\section{PENDAHULUAN}

Salah satu hal yang dikritisi oleh masyarakat adalah tentang kinerja pegawai publik pada sektor layanan dibidang kepabeanan dan cukai khususnya pada Kantor Pengawasan dan Pelayanan Bea dan Cukai Tipe Madya Pabean B Makassar (KPPBC Tipe Madya Pabean B Makassar).

KPPBC Tipe Madya Pabean B Makassar berusaha untuk terus memberikan kinerja dan pelayanan yang baik dalam rangka melaksanakan asas pemerintahan yang baik. Untuk dapat membentuk sosok PNS yang berkinerja tinggi, perlu dilaksanakan pembinaan melalui jalur pendidikan dan pelatihan yang mengarah pada upaya peningkatan sikap dan semangat pengabdian yang berorientasi pada kepentingan masyarakat, bangsa, negara dan tanah air, kompetensi teknis, manajerial dan atau kepemimpinannya, efisiensi, efektivitas dan kualitas pelaksanaan tugas yang dilakukan dengan semangat kerjasama dan tanggung jawab sesuai dengan lingkungan kerja dan organisasi.

KPPBC Tipe Madya Pabean B Makassar turut serta melaksanakan pendidikan dan pelatihan demi upaya peningkatan kinerja pegawainya. Jenis diklat yang dilakukan oleh pegawai KPPBC Tipe Madya Pabean B Makassar antara lain Diklat Teknis Umum, Diklat Teknis Subtantif, Diklat Fungsional, Kerjasama Diklat, Penyegaran, dan Diklat Jarak Jauh/E-Learning. Upaya positif lainnya dalam rangka meningkatkan kinerja pegawai adalah memberikan motivasi bagi pegawai tersebut misalnya dalam bentuk pelatihan Service Level Agreement (SLA), Capacity Building dan peningkatan kapasitas mental dan spiritual yang diharapkan akan membentuk karakter dan sikap positif dalam diri setiap pegawai.

Pihak organisasi harus memberikan kebutuhan tersebut sehingga para pegawai dapat melaksanakan tugasnya secara maksimal. Apabila kebutuhan pegawai tidak terpenuhi, maka pegawai tersebut akan menunjukkan perilaku yang pasif dan tidak produktif. Sebaliknya, jika kebutuhannya terpenuhi maka pegawai tersebut akan menunjukkan perilaku yang gembira serta produktif sebagai manifestasi dari rasa puasnya.

KPPBC Tipe Madya Pabean B Makassar telah berusaha memberikan pelayanan dalam bidang kepabeanan dan cukai dengan baik dan juga senantiasa berusaha menyediakan fasilitas-fasilitas yang mendukung bagi peningkatan kompetensi dan motivasi pegawainya dalam usaha mencapai hasil kinerja organisasi yang diharapkan. Hal ini terlihat dalam laporan kinerja KPPBC Tipe Madya Pabean B Makassar selama tiga tahun terakhir mampu mencapai target yang telah ditetapkan, sebagaimana tabel berikut: 


\section{Tabel 1. Capaian Indikator Kinerja Utama KPPBC Tipe Madya Pabean B Makassar Tahun 2017-2019}

\begin{tabular}{|c|c|c|c|c|c|c|c|}
\hline \multirow[b]{2}{*}{$\begin{array}{l}\mathrm{N} \\
\mathrm{o}\end{array}$} & \multirow[b]{2}{*}{ Deskripsi } & \multicolumn{2}{|c|}{2017} & \multicolumn{2}{|c|}{2018} & \multicolumn{2}{|c|}{2019} \\
\hline & & Target & $\begin{array}{c}\text { Reali } \\
\text { sasi }\end{array}$ & Target & $\begin{array}{c}\text { Reali } \\
\text { sasi }\end{array}$ & Target & $\begin{array}{c}\text { Reali } \\
\text { sasi }\end{array}$ \\
\hline 1 & $\begin{array}{l}\text { Persentase realisasi } \\
\text { penerimaan bea } \\
\text { dan cukai }\end{array}$ & $100 \%$ & $111,19 \%$ & $100 \%$ & $110,79 \%$ & $100 \%$ & $104,94 \%$ \\
\hline 2 & $\begin{array}{l}\text { Indeks } \\
\text { Kepuasan } \\
\text { Pengguna Jasa }\end{array}$ & $\begin{array}{l}4 \\
\text { (skala 5) }\end{array}$ & 4.59 & $\begin{array}{l}4.27 \\
\text { (skala } \\
5)\end{array}$ & 4.55 & 4.30 & $\begin{array}{l}4.75 \\
\text { (skala 5) }\end{array}$ \\
\hline 3 & $\begin{array}{ll}\text { Rata-rata } & \\
\text { persentasi } & \text { realisasi } \\
\text { janji } & \text { layanan } \\
\text { kepabeanan dan } \\
\text { cukai }\end{array}$ & $100 \%$ & $118,58 \%$ & $100 \%$ & $110,20 \%$ & $100 \%$ & $109,62 \%$ \\
\hline 4 & $\begin{array}{l}\text { Persentasi } \\
\text { peningkatan } \\
\text { kompetensi } \\
\text { pegawai } \\
\text { (*indeks } \\
\text { efektivitas) }\end{array}$ & $80^{*}$ & $91^{*}$ & $60 \%$ & $83,58 \%$ & $70 \%$ & $92,93 \%$ \\
\hline
\end{tabular}

Sumber: Data primer, 2020

Dari tabel Laporan Kinerja KPPBC Tipe Madya Pabean B Makassar menunjukkan bahwa pencapaian realisasi penerimaan kepabeanan dan cukai diikuti dengan peningkatan kualitas layanan serta peningkatan kompetensi pegawai pada KPPBC Tipe Madya Pabean B Makassar.

Pencapaian hasil kinerja KPPBC Tipe Madya Pabean B Makassar tidak lepas dari dukungan unsur pimpinan yang senantiasa memotivasi setiap pegawainya untuk meningkatkan kompetensi sesuai bidang tugasnya masing-masing. Veithzal (2004:26) mengatakan bahwa kompetensi adalah kemampuan sumber daya manusia dalam melaksanakan aktivitas kerja karena latar belakang pendidikan, pengetahuan, keahlian dan percaya diri yang tinggi terhadap tugas.

KPPBC Tipe Madya Pabean B Makassar menyadari bahwa dengan peningkatan kompetensi dan motivasi setiap pegawai akan membawa hasil yang positif bagi organisasi dalam pencapaian target kinerja sebagaimana pendapat (Suharsaputra, 2010) yang menjelaskan bahwa faktor kemampuan/kompetensi dapat mempengaruhi kinerja karena dengan kemampuan yang tinggi, maka kinerja pegawai pun akan tercapai. Hal ini diperkuat dengan pendapat (Mangkunegara, 2005) mengatakan bahwa kinerja adalah merupakan hasil kerja secara kualitas dan 
kuantitas yang dicapai oleh seseorang dalam melaksanakan fungsinya sesuai dengan tanggung jawab yang diberikan kepadanya.

Hubungan antara peningkatan kompetensi dengan kinerja organisasi salah satunya dapat terlihat dari hasil penelitian oleh (Rande, 2019) yang menunjukkan bahwa besarnya pengaruh kompetensi secara parsial terhadap kinerja pegawai Dinas Perhubungan, Komunikasi dan Informatika Kabupaten Mamuju Utara ditentukan oleh pengetahuan (knowledge) dan keterampilan (skills).

Peningkatan kompetensi aparatur pemerintahan tersebut sejalan dengan program pemerintah dalam penyederhanaan birokrasi pemerintahan menjadi 2 level eselon serta mengganti jabatan eselon dengan jabatan fungsional yang lebih menghargai keahlian dan kompetensi Aparatur Sipil Negara yang pada dasarnya bertujuan bahwa pemerintah ingin membangun profesionalisme birokrasi, menciptakan akuntabilitas pemerintahan, memperkuat tanggung jawab pejabat atas putusan tindakan administrasi dan untuk menciptakan efisiensi dan efektifitas birokrasi yang pada akhirnya membangun budaya yang unggul yang berorientasi pada kinerja.

Grand theory mengenai kompetensi berdasarkan teori yang dikemukakan oleh (Cicuta \& Donald, 2007) menyatakan bahwa kompetensi adalah sentral dari keberhasilan mencapai kinerja yang dipengaruhi oleh adanya pengetahuan, keterampilan, keahlian dan sikap. Akses pengembangan diri pada dasarnya adalah pengenalan tentang kompetensi sumber daya manusia dengan memperkenalkan teori "Window" atau lazim disebut teori "Jendela", bahwa setiap pengembangan diri yang dimiliki manusia diamati atau dilihat dari empat sisi yang berbentuk jendela yaitu pengetahuan (knowledge), keterampilan (skill), keahlian (expert), dan sikap (attitude).

Melalui teori ini, kompetensi merupakan perpaduan unik. Dari keempat faktor tersebut, seiring dengan berjalannya waktu dengan treatment yang tepat, sumber daya manusia akan memiliki keunggulan kompetitif. Personil sumber daya manusia saat ini tidak hanya memiliki kompetensi agar dapat sukses, tapi perlu unggul secara kompetitif dibandingkan personil-personil lainnya.

\section{Kerangka Konseptual}

\section{Gambar 1. Kerangka Konseptual Penelitian}

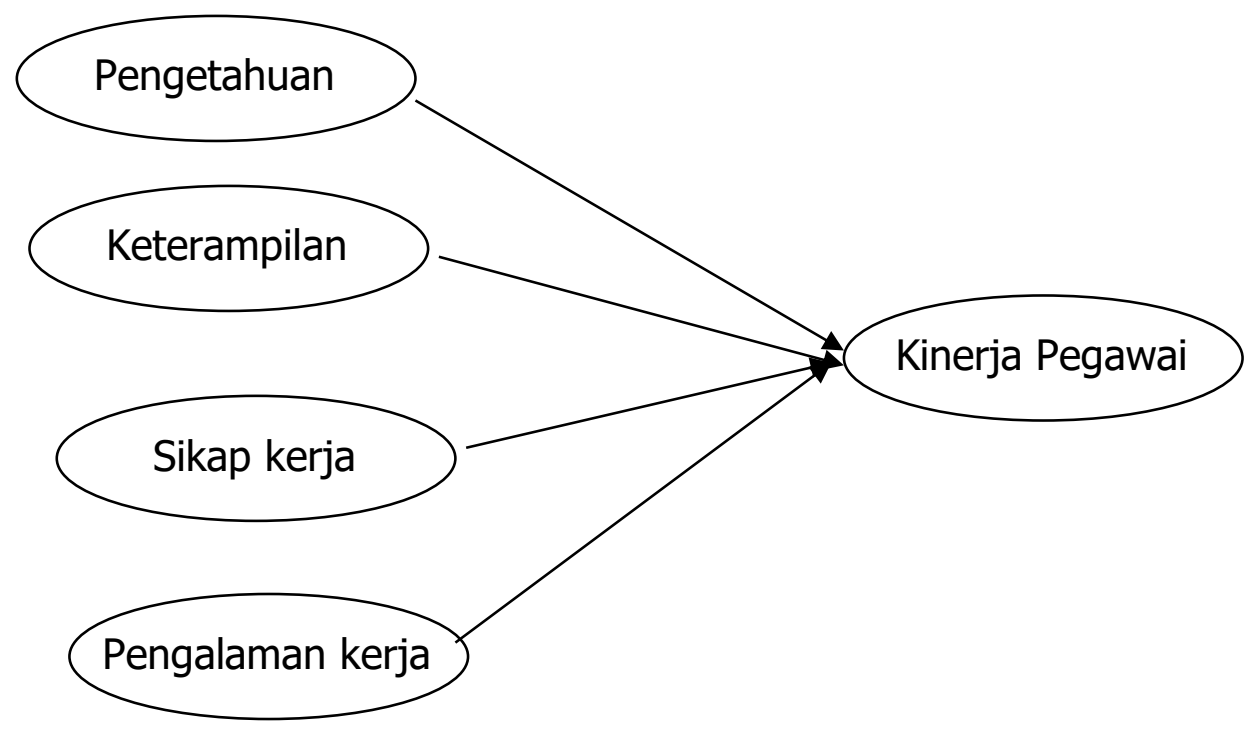




\section{Hipotesis}

Berdasarkan gambaran sebagaimana telah dikemukakan, maka dapat dibuat hipotesis atau dugaan sementara bahwa:

1. Pengetahuan berpengaruh terhadap kinerja Pegawai KPPBC Tipe Madya Pabean B Makassar.

2. Keterampilan berpengaruh terhadap kinerja Pegawai KPPBC Tipe Madya Pabean B Makassar.

3. Sikap kerja berpengaruh terhadap kinerja Pegawai KPPBC Tipe Madya Pabean B Makassar.

4. Pengalaman kerja berpengaruh terhadap kinerja Pegawai KPPBC Tipe Madya Pabean B Makassar

\section{METODE PENELITIAN}

Pendekatan penelitian ini merupakan penelitian kuantitatif. Metode penelitian kuantitatif dapat diartikan sebagai metode yang digunakan untuk meneliti populasi atau sampel tertentu, pengumpulan data menggunakan instrumen penelitian, analisa data bersifat statistik, dengan tujuan untuk menguji hipotesis yang telah ditetapkan. Untuk mendapatkan data dan informasi yang diperlukan yang berkaitan atau relevan dengan permasalahan yang dibahas dalam tesis ini guna mempermudah pembahasan dan penyelesaian penulisan, maka penulis melakukan penelitian yang berlokasi pada KPPBC Tipe Madya Pabean B Makassar; Jalan Hatta No.2, Makassar.

\section{Hipotesis}

Untuk menguji kebenaran hipotesis yang telah dirumuskan sebelumnya, maka metode analisis yang digunakan adalah sebagai berikut:

1. Analisis Deskriptif, digunakan untuk menjelaskan frekuensi tanggapan responden penelitian sesuai hasil tabulasi variabel kompetensi (pengetahuan, keterampilan, sikap kerja dan pengalaman kerja).

2. Analisis regresi linear berganda, digunakan untuk menghitung besarnya pengaruh dan signifikansi masing-masing variabel kompetensi terhadap kinerja pegawai KPPBC Tipe Madya Pabean B Makassar. Adapun formulasi mengenai regresi linear berganda dapat ditunjukkan sebagai berikut:

$$
\begin{array}{ll}
\mathrm{Y} & =\beta_{0}+\beta_{1} \mathrm{X}_{1}+\beta_{2} \mathrm{X}_{2}+\beta_{3} \mathrm{X}_{3}+\beta_{4} \mathrm{X}_{4}+\varepsilon_{\mathrm{i}} \\
\operatorname{dimana}: & =\text { Kinerja Pegawal } \\
\mathrm{Y} & =\text { Konstanta } \\
\beta 0 & =\text { Koefisien Regresi } \\
\beta 1-\beta 4 & =\text { Pengetahuan } \\
\mathrm{X} 1 & =\text { Keterampilan } \\
\mathrm{X} 2 & =\text { Sikap Kerja } \\
\mathrm{X} 3 & =\text { Pengalaman Kerja } \\
\mathrm{X} 4 & =\text { Standar Error } \\
\varepsilon \mathrm{i} &
\end{array}
$$

Selanjutnya untuk melihat pengaruh dari masing-masing variabel, dilanjutkan 
dengan pengujian hipotesis sebagai berikut:

a. Uji-F (Fisher)

Menurut (Sujana, 1997), Uji F digunakan untuk menguji apakah variabel X secara bersama-sama berpengaruh terhadap Y. Uji simultan ini dilakukan dengan membandingkan nilai F-hitung dengan F-tabel, jika F-hitung > F-tabel, atau juga dapat dilihat dari besarnya probabilitas yaitu $\mathrm{P}>\alpha=0,05$ maka terdapat pengaruh signifikan, sebaliknya jika nilai F-hitung $<$ F-tabel, atau jika $\mathrm{P}<\alpha=$ 0,05 maka tidak terdapat pengaruh signifikan.

b. Uji-t (Student)

Menurut (Algifari, 1997), Uji t digunakan untuk membuat kesimpulan mengenai pengaruh masing-masing variabel independen (X1-X4) terhadap variabel dependen $(\mathrm{Y})$. Uji parsial ini dilakukan dengan membandingkan nilai t-hitung dengan t-tabel. Jika nilai t-hitung $>$ t-tabel atau juga dapat dilihat dari besarnya probabilitas yaitu $\mathrm{P}>\alpha=0,05$ maka variabel independen berpengaruh terhadap variabel dependen. Demikian pula sebaliknya Jika nilai t-hitung $<\mathrm{t}$-tabel atau juga dapat dilihat dari besarnya probabilitas yaitu $\mathrm{P}<\alpha=0,05$ maka variabel independen tidak berpengaruh terhadap variabel dependen.

Dalam pendugaan parameter analisis yang umum digunakan adalah metode kwadrat terkecil, dimana asumsinya (Gujarati, 2012:132), yaitu:

a. Rata-rata gangguan sama dengan nol. $\mathrm{E}(\mathrm{e})=0$. Dalam asumsi ini mengharap model yang dipakai dapat secara tepat menggambarkan rata-rata variabel tergantung dalam setiap observasi. Di sini, jika sampel diulang dengan nilai variabel yang tetap, maka kesalahan dalam setiap observasi mempunyai ratarata $=$ nol atau saling meniadakan .

b. Homoskedastisitas $\mathrm{E}\left(\mathrm{e}^{2}\right)=0^{2}$. Dalam hal ini dimaksudkan adanya varians gangguan tidak berbeda dari satu observasi ke observasi lainnya atau dapat dikatakan setiap observasi mempunyai reliabilitas yang sama.

c. Non Otokorelasi E (ej) = 0, artinya, jika gangguan di satu observasi tidak bervariasi, maka akan diobservasi yang lain. Nilai variabel tergantung hanya diterangkan oleh variabel bebas dan bukan variasi gangguan (error).

d. Non Multicolinearity E (ej, $\left.X_{j}\right)=0$, artinya variabel gangguan tidak berkorelasi dengan variabel bebas. Asumsi ini mempunyai implikasi, nilai variabel bebas tidak berubah dari satu sampel ke sampel lainnya, karena variabel bebas ini terlihat pengaruhnya terhadap variabel terikat.

\section{HASIL PENELITIAN DAN PEMBAHASAN}

Hasil

Uji Normalitas 
Tabel 1. Hasil Uji Normalitas

\begin{tabular}{|c|c|c|}
\hline \multicolumn{2}{|l|}{$\mathrm{N}$} & $\begin{array}{c}\text { Unstandardized } \\
\text { Residual } \\
112\end{array}$ \\
\hline \multirow[t]{2}{*}{ Normal Parameters } & Mean & .0000000 \\
\hline & Std. Deviation & .18305261 \\
\hline \multirow[t]{3}{*}{$\begin{array}{l}\text { Most Extreme } \\
\text { Differences }\end{array}$} & Absolute & .075 \\
\hline & Positive & .058 \\
\hline & Negative & -.075 \\
\hline Test Statistic & & .075 \\
\hline $\begin{array}{l}\text { Asymp. Sig (2- } \\
\text { tailed) }\end{array}$ & & $.159^{c}$ \\
\hline
\end{tabular}

Sumber: Data primer, 2020

Berdasarkan tabel 15 yakni hasil uji normalitas dengan nilai sig $=0,159>0,05$ berarti dapat disimpulkan bahwa data yang akan digunakan dalam pengujian regresi memiliki distribusi yang normal, alasannya karena memiliki nilai sig $>0,05$.

\section{Uji Multikolinearitas}

\section{Tabel 2. Hasil Uji Multikolinearitas}

\begin{tabular}{lccccc}
\multirow{2}{*}{ Variabel } & \multicolumn{2}{c}{$\begin{array}{c}\text { Colineritas } \\
\text { Statistik }\end{array}$} & VIF & \multirow{2}{*}{ Keputusan } \\
\cline { 2 - 4 } & Tolerance & VIF & Standar & \\
\hline PENGETAHUAN (X1) & .491 & 2.038 & 10 & $\begin{array}{l}\text { Tidak ada gejala } \\
\text { multikoliearitas }\end{array}$ \\
\hline KETERAMPILAN (X2) & .416 & 2.401 & 10 & $\begin{array}{l}\text { Tidak ada gejala } \\
\text { multikoliearitas }\end{array}$ \\
\hline SIKAP (X3) & .463 & 2.161 & 10 & $\begin{array}{l}\text { Tidak ada gejala } \\
\text { multikoliearitas }\end{array}$ \\
\hline PENGALAMAN (X4) & .345 & 2.899 & 10 & $\begin{array}{l}\text { Tidak ada gejala } \\
\text { multikoliearitas }\end{array}$ \\
\hline
\end{tabular}

Sumber: Data primer, 2020

Dari hasil uji multikolinearitas pada tabel 16 menunjukkan bahwa semua variabel memilliki nilai VIF $<10$ dan nilai toleransinya $>0,1$. Ini menunjukkan bahwa tidak ada indikasi keberadaan multikolinearitas pada persamaan yang dilakukan dan tidak terbukti atau tidak terdapat multikolinearitas dalam persamaan yang dilakukan atau hubungan yang terjadi antar variabel bebas dapat ditoleransi sehingga tidak akan mengganggu hasil regresi. 
Pengaruh Kompetensi Terhadap ... (Muchlis, Mus \& Imaduddin) | 186

Uji Heteroskedastisitas

Gambar 2. Hasil Uji Heteroskedastisitas

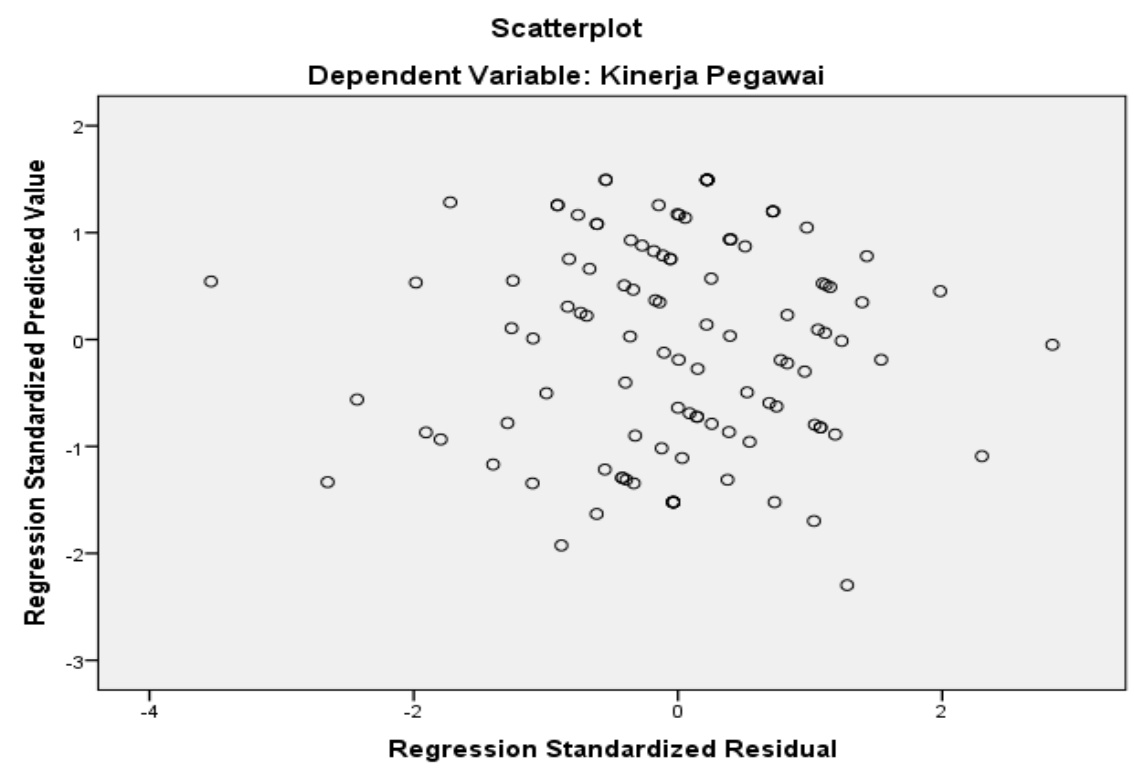

Pengujian Hipotesis

Pengujian Hipotesis Secara Serempak (Uji-F)

Tabel 3. Hasil Uji-F (Simultan)

\begin{tabular}{cccccc}
\hline Model & $\begin{array}{c}\text { Sum of } \\
\text { Squares }\end{array}$ & Df & $\begin{array}{c}\text { Mean } \\
\text { Square }\end{array}$ & F & Sig. \\
\hline Regression & 11.079 & 4 & 2.770 & 79.678 & $.000^{\mathrm{b}}$ \\
\hline Residual & 3.719 & 107 & .035 & & \\
\hline Total & 14.798 & 111 & & &
\end{tabular}

Sumber: Data primer, 2020

Pengujian Hipotesis Secara Parsial (Uji-t)

Tabel 4. Hasil Uji-t (Parsial)

\begin{tabular}{|c|c|c|c|c|c|}
\hline & & $\begin{array}{l}\text { Unstadardized } \\
\text { Coefficients }\end{array}$ & $\begin{array}{l}\text { Standardized } \\
\text { Coefficients }\end{array}$ & & \\
\hline & B & Std. Error & Beta & $\mathbf{t}$ & Sig \\
\hline (Constant) & .198 & .247 & & .801 & .425 \\
\hline Pengetahuan (X1) & .199 & .060 & .229 & 3.303 & .001 \\
\hline Keterampilan (X2) & .149 & .066 & .171 & 2.275 & .025 \\
\hline Sikap Kerja (X3) & .465 & .072 & .462 & 6.491 & .000 \\
\hline $\begin{array}{l}\text { Pengalaman Kerja } \\
(\mathrm{X} 4)\end{array}$ & .139 & .068 & .169 & 2.051 & .043 \\
\hline
\end{tabular}

Sumber: Data primer, 2020 
Tabel 5. Regresi Linear Berganda

\begin{tabular}{lccccc} 
& \multicolumn{7}{c}{$\begin{array}{c}\text { Unstadardized } \\
\text { Coefficients }\end{array}$} & $\begin{array}{c}\text { Standardized } \\
\text { Coefficients }\end{array}$ & & \\
& $\mathbf{B}$ & Std. Error & Beta & t & Sig \\
\hline (Constant) & .198 & .247 & & .801 & .425 \\
\hline Pengetahuan (X1) & .199 & .060 & .229 & 3.303 & .001 \\
\hline $\begin{array}{l}\text { Keterampilan } \\
(X 2)\end{array}$ & .149 & .066 & .171 & 2.275 & .025 \\
\hline Sikap (X3) & .465 & .072 & .462 & 6.491 & .000 \\
\hline Pengalaman (X4) & .139 & .068 & .169 & 2.051 & .043 \\
\hline \multicolumn{2}{l}{ Sumber: Data primer, 2020} & & & &
\end{tabular}

\section{Pengujian Koefisien Determinasi}

Tabel 6. Hasil Uji Koefisien Determinasi

\begin{tabular}{ccccc} 
Model & $\mathrm{R}$ & $\mathrm{R}$ Square & $\begin{array}{c}\text { Adjusted R } \\
\text { Square }\end{array}$ & $\begin{array}{c}\text { Std. Error of the } \\
\text { Estimate }\end{array}$ \\
\hline 1 & $.865^{\mathrm{a}}$ & .749 & .739 & .186 \\
\hline
\end{tabular}

Sumber: Data primer, 2020

\section{Pembahasan}

\section{Pengaruh Pengetahuan Terhadap Kinerja Karyawan}

Hasil penelitian ini diperoleh t-hitung untuk pengetahuan sebesar 3,303 dan untuk nilai $\mathrm{t}$-tabel dari hasil $\mathrm{n}-\mathrm{k}-1$ ( $\mathrm{n}=$ responden, $\mathrm{k}=$ variabel independen) sebesar 1,659. Dengan begitu berdasarkan nilai t-hitung sebesar 3,303 > 1,659 dan untuk nilai probabilitas sebesar 0,001 < 0,05 maka dapat disimpulkan H0 ditolak dan Ha diterima, dengan demikian pengetahuan berpengaruh signifikan secara parsial terhadap kinerja pegawai.

Pengetahuan pegawai turut menentukan berhasil tidaknya pelaksanaan tugas yang dibebankan kepadanya, pegawai yang mempunyai pengetahuan yang cukup akan meningkatkan efisiensi perusahaan. Namun bagi pegawai yang belum mempunyai pengetahuan cukup, maka akan bekerja tersendat-sendat. Pemborosan bahan, waktu dan tenaga serta faktor produksi yang lain akan diperbuat oleh pegawai berpengetahuan kurang. Pemborosan ini akan mempertinggi biaya dalam pencapaian tujuan instansi.

Hasil penelitian ini sejalan dengan penelitian yang telah dilakukan oleh Alias (2018) yang meneliti masalah "Pengaruh Pengetahuan, Sikap Kerja dan Pengalaman Kerja terhadap Kinerja Karyawan Kantor BPJS Makassar". Alias memperoleh hasil bahwa pengetahuan memiliki pengaruh yang besar terhadap kinerja karyawan.

Fakta yang terjadi dilingkungan kerja KPPBC Tipe Madya Pabean B Makassar dengan memotivasi pada pegawainya untuk melanjutkan jenjang pendidikan guna meningkatkan kemampuan mereka dalam setiap menghadapi permasalahan 
mereka serta dalam mengambil langkah dan keputusan yang terbaik. Dengan adanya peningkatan pengetahuan para pegawai mampu bekerja dengan baik dan dapat berfikir secara konseptual dalam setiap pekerjaannya, mereka yang memiliki pengetahuan akan berfikir secara logis agar mampu menghadapi setiap jenis permasalahan yang terjadi di lingkungan kantor. Kemampuan yang dimiliki oleh setiap pegawai berbeda-beda dikarenakan tingkat pendidikan dan pengetahuan yang berbeda sehingga hal inilah yang mendorong pimpinan untuk memotivasi para staf nya untuk senantiasa melanjutkan pendidikan dan memberikan pelatihan secara intens agar pengetahuan yang pegawai miliki dengan sendirinya terasah dengan baik. Dari beberapa jenis pelatihan yang telah dilaksanakan oleh KPPBC Tipe Madya Pabean B Makassar yang lebih sering dilakukan adalah metode $e$ learning, pelaksanaan diklat berbasis kompetensi, on the job training dan metode demonstrasi karena lebih efektif dan mudah dalam pelaksanaannya.

Pengetahuan sangat diperlukan pegawai untuk mencapai suatu tingkat atau standar yang telah ditetapkan pada suatu pekerjaan tertentu. Pengetahuan yang dimiliki dapat juga bermanfaat bagi pegawai secara individual karena memungkinkan mereka memperoleh nilai tambah dan bahkan mungkin dapat membentuk sikap positif pegawai yang bermanfaat bagi organisasi.

\section{Pengaruh Keterampilan Terhadap Kinerja Karyawan}

Hasil penelitian ini diperoleh t-hitung untuk keterampilan sebesar 2,275 dan untuk nilai $\mathrm{t}$-tabel dari hasil $\mathrm{n}-\mathrm{k}-1$ ( $\mathrm{n}=$ responden, $\mathrm{k}=$ variabel independen) sebesar 1,659. Dengan begitu berdasarkan nilai t-hitung sebesar 2,275 > 1,659 dan untuk nilai probabilitas sebesar 0,025 < 0,05 maka dapat disimpulkan H0 ditolak dan Ha diterima, dengan demikian keterampilan berpengaruh signifikan secara parsial terhadap kinerja pegawai.

Pegawai yang mempunyai keterampilan kerja yang baik maka akan mempercepat pencapaian tujuan organisasi, sebaliknya pegawai yang tidak terampil akan memperlambat tujuan organisasi. Untuk pegawai-pegawai baru atau pegawai dengan tugas baru diperlukan tambahan keterampilan guna pelaksanaan tugastugas yang dibebankan kepadanya.

Fakta yang terjadi pada lingkungan KPPBC Tipe Madya Pabean B Makassar adalah dengan latar belakang pendidikan yang sesuai serta pelaksanaan pelatihan yang dilakukan peningkatan kinerja pegawai semakin baik, tingkat kreativitas bekerja dan cara pegawai menyelesaikan pekerjaan dengan kreativitas yang dimiliki mampu bekerja lebih cepat setelah dilaksanakan training bagi pegawai baru, pengetahuan yang dimiliki pegawai mampu mendorong pegawai dalam pengambilan keputusan dari setiap permasalahan yang sering terjadi, adanya komunikasi antara rekan kerja dalam kantor akan menciptakan lingkungan kerja yang nyaman dan membantu dalam penyelesaian pekerjaan. Pada saat ini pula KPPBC Tipe Madya Pabean B Makassar sudah menerapkan penempatan pegawai yang disesuaikan dengan disiplin ilmu dan materi diklat yang telah mereka miliki sehingga mereka mampu menyelesaikan pekerjaannya sesuai dengan 
keterampilan yang dimilikinya serta seorang pemimpin yang selalu memotivasi pegawainya agar mampu bekerja lebih baik, hal ini pula yang mampu mendorong pegawai dalam meningkatkan kinerjanya.

Hasil penelitian ini sejalan dengan penelitian yang dilakukan oleh (Lengkong, Legkong \& Taroreh, 2019) yang meneliti masalah "Pengaruh Keterampilan, Pengalaman dan Lingkungan Kerja terhadap Kinerja Karyawan PT. Tri Mustika Cocominaesa (Minahasa Selatan)" yang memperoleh hasil bahwa keterampilan sangat berpengaruh terhadap kinerja karyawan. (Sari, et.all, 2019) juga meneliti masalah "Pengaruh Tingkat Pendidikan, Keterampilan Kerja, dan Sikap Kerja terhadap Kinerja Karyawan pada Perusahaan Daerah Air Minum (PDAM) Kota Padang" yang juga memperoleh hasil bahwa keterampilan mempunyai pengaruh terhadap kinerja karyawan.

\section{Pengaruh Sikap Kerja Terhadap Kinerja Karyawan}

Hasil penelitian ini diperoleh t-hitung untuk sikap sebesar 6,491 dan untuk nilai ttabel dari hasil n-k-1 (n=responden, $\mathrm{k}=$ variabel independen) sebesar 1,659. Dengan begitu berdasarkan nilai t-hitung sebesar 6,491>1,659 dan untuk nilai probabilitas sebesar 0,000 < 0,05 maka dapat disimpulkan H0 ditolak dan Ha diterima, dengan demikian sikap berpengaruh signifikan secara parsial terhadap kinerja pegawai.

Disamping pengetahuan dan keterampilan pegawai, hal yang perlu diperhatikan adalah sikap atau perilaku kerja pegawai. Apabiia pegawai mempunyai sifat yang mendukung pencapaian tujuan organisasi, maka secara otomatis segala tugas yang dibebankan kepadanya akan dilaksanakan dengan sebaik-baiknya.

Fakta yang terjadi pada KPPBC Tipe Madya Pabean B Makassar menunjukkan bahwa para pegawai senantiasa ingin menunjukkan sikap kerja dengan menciptakan keharmonisan dalam pekerjaannya. Salah satu cara pegawai menunjukkan sikap yang ramah saling meringankan beban teman, serta berkomunikasi dengan baik merupakan wujud dari keharmonisan di lingkungan kerja, serta jika terjadi permasalahan pemimpin turun langsung untuk menjembatani prselisihan yang terjadi sehingga antara satu pegawai dengan pegawai lainnya tidak saling berselisih faham. Para pegawai juga menunjukkan integritas yang tinggi pada saat mereka diberikan tugas dan tanggung jawab mereka berusaha menyelesaikan tugas tersebut sesuai dengan prosedur dan waktu yang telah ditentukan oleh karena itu sikap yang ditunjukkan oleh para pegawai merupakan bagian sikap kerja yang senantiasa harus dijaga dan selalu diperbaiki agar dapat terwujud peningkatan kinerja yang diinginkan bersama.

Hal tersebut diatas sejalan dengan pendapat dari (Mulyasa, 2003) mengemukakan bahwa beberapa aspek atau ranah yang terkandung dalam konsep kompetensi sumber daya manusia dalam setiap organisasi, yaitu: (1) pengetahuan (knowledge), kesadaran dalam bidang kognitif, (2) pemahaman (understanding) yaitu kedalaman kontif dan efektif yang dimiliki oleh setiap individu, (3) keterampilan (skills) adalah sesuatu yang dimiliki individu untuk melakukan pekerjaan yang 
dibebankan kepadanya, (4) nilai (value) adalah suatu standar perilaku yang lebih diyakini dan secara psikologis telah menyatu dalam diri seseorang, (5) sikap (attitude) yaitu perasaan senang atau tidak senang atau reaksi terhadap suatu rangsangan yang bersumber dari luar, (6) minat (interest) adalah kecenderungan seseorang untuk melakukan sesuatu perbuatan atau kegiatan.

Hasil penelitian ini sejalan dengan penelitian yang telah dilakukan oleh (Margaretha, 2012) yang meneliti masalah "Pengaruh Sikap Kerja terhadap Kinerja Karyawan pada PT. Duta Marga Silima Jakarta". Meily memperoleh hasil bahwa sikap kerja memiliki pengaruh terhadap kinerja karyawan. Penelitian yang dilakukan oleh Robert Korompis pada tahun 2017 yang meneliti masalah "Pengaruh Sikap Kerja dan Kompensasi terhadap Kinerja Karyawan pada PT. Bank Negara Indonesia Manado", juga mendapatkan hasil penelitian bahwa sikap kerja berpengaruh terhadap kinerja karyawan.

Hal ini didukung oleh (Mangkunegara, 2005) yang mengatakan kompetensi sumber daya manusia adalah yang berhubungan dengan pengetahuan, keterampilan, kemampuan dan karakteristik kepribadian yang dapat mempengaruhi secara langsung terhadap kinerja sumber daya manusia pada kondisi perubahan organisasi.

\section{Pengaruh Pengalaman Kerja Terhadap Kinerja Karyawan}

Hasil penelitian ini diperoleh untuk t-hitung pengalaman sebesar 2,051 dan untuk nilai t-tabel dari hasil n-k-1 ( $\mathrm{n}=$ responden, $\mathrm{k}=$ variabel independen) sebesar 1,659. Dengan begitu berdasarkan nilai t-hitung sebesar 2,051 > 1,659 dan untuk nilai probabilitas sebesar 0,043 < 0,05 maka dapat disimpulkan H0 ditolak dan Ha diterima, dengan demikian pengalaman berpengaruh signifikan secara parsial terhadap kinerja pegawai.

Fakta yang terjadi pada KPPBC Tipe Madya Pabean B Makassar menunjukkan bahwa dengan pengalaman kerja pegawai mampu bertanggung jawab atas pekerjaan yang sudah mereka laksanakan, integritas yang tinggi dan rasa tanggung jawab besar membuat pegawai bersemangat dalam melaksanakan tugastugasnya. Pengalaman kerja yang dimiliki oleh masing-masing pegawai berbedabeda dikarenakan penempatan kerja yang berbeda sehingga mereka mempunyai kelebihan dalam bidang kerjanya masing-masing. Pengalaman kerja yang dimiliki mampu mewujudkan kinerja yang tinggi hal ini dikarenakan faktor pengalaman merupakan hal yang sangat penting dalam menilai kompetensi pegawai tersebut.

Dengan banyaknya pengalaman terdapat kemungkinan besar untuk mewujudkan kinerja yang baik dan sebaliknya bila tidak cukup berpengalaman dalam melaksanakan tugasnya, seseorang kemungkinan besar akan mengalami kegagalan.

Penelitian ini sejalan dengan penelitian yang telah dilakukan oleh (Anggriawan, 2014) yang meneliti masalah "Pengaruh Pengalaman Kerja, Skeptisme Profesional dan Tekanan Waktu terhadap Kinerja Karyawan". Anggriawan memperoleh hasil 
bahwa pengalaman kerja berpengaruh positif dan signifikan terhadap kinerja karyawan. (Arifudin, 2018) juga meneliti masalah "Pengaruh Pengalaman Kerja terhadap Kinerja Karyawan PT. Bank Negara Indonesia Tbk Cabang Bumi Serpong". Bachtiar memperoleh hasl bahwa pengalaman kerja berpengaruh terhadap kinerja karyawan.

\section{KESIMPULAN}

Hasil pengujian hipotesis membuktikan bahwa pengetahuan kerja pegawai memiliki pengaruh positif dan signifikan terhadap peningkatan kinerja pegawai pada KPPBC Tipe Madya Pabean B Makassar. Hasil pengujian hipotesis membuktikan bahwa keterampilan kerja memiliki pengaruh positif dan signifikan terhadap peningkatan kinerja pegawai pada KPPBC Tipe Madya Pabean B Makassar. Hasil pengujian hipotesis membuktikan bahwa sikap kerja memiliki pengaruh positif dan signifikan terhadap peningkatan kinerja pegawai pada KPPBC Tipe Madya Pabean B Makassar. Hasil pengujian hipotesis membuktikan bahwa pengalaman kerja memiliki pengaruh positif dan signifikan terhadap peningkatan kinerja pegawai pada KPPBC Tipe Madya Pabean B Makassar. Kontribusi kompetensi yang terdiri dari pengetahuan keterampilan, sikap kerja dan pengalaman kerja secara serempak berpengaruh positif terhadap kinerja pegawai pada KPPBC Tipe Madya Pabean B Makassar.

\section{DAFTAR PUSTAKA}

Algifari (1997) Statistika Induktif untuk Ekonomi dan Bisnis. UPP AMP YKPN. Yogyakarta

Anggriawan, E. F. (2014). Pengaruh pengalaman kerja, skeptisme profesional dan tekanan waktu terhadap kemampuan auditor dalam mendeteksi fraud (Studi empiris pada Kantor Akuntan Publik di DIY). Nominal: Barometer Riset Akuntansi dan Manajemen, 3(2), 101-116.

Cicuta, P., \& Donald, A. M. (2007). Microrheology: a review of the method and applications. Soft matter, 3(12), 1449-1455.

Husain, B. A. (2018). Pengaruh Disiplin Kerja Terhadap Kinerja Karyawan (Pada PT. Bank Danamon Tbk Cabang Bintaro). Jurnal Disrupsi Bisnis: Jurnal Ilmiah Prodi Manajemen, Fakultas Ekonomi, Universitas Pamulang, 1(1), 1-16.

Lengkong, F., Lengkong, V. P., \& Taroreh, R. N. (2019). Pengaruh Keterampilan, Pengalaman dan Lingkungan Kerja terhadap Kinerja Karyawan di PT. Tri Mustika Cocominaesa (Minahasa Selatan). Jurnal EMBA: Jurnal Riset Ekonomi, Manajemen, Bisnis dan Akuntansi, 7(1).

Mangkunegara, A. A. P. (2005). Evaluasi kinerja SDM. Tiga Serangkai.

Margaretha, M., \& Natalia, N. (2012). Pengaruh sikap kerja terhadap kinerja karyawan pada PT. Duta Marga Silima di Jakarta. Jurnal Manajemen dan Bisnis, 2(2), 151-166.

Mulyasa, E. (2003). Manajemen berbasis kompetensi dan Aplikasinya. Bandung: Rosdakarya, 101-105. 
Rande, D. (2017). Pengaruh Kompetensi terhadap kinerja pegawai pada dinas perhubungan, komunikasi dan informatika kabupaten Mamuju Utara. Katalogis, 4(2).

Sari, V. N., Sari, M. W., Mulyani, S. R., \& Defit, S. (2019, September). Analisis Dan Usulan Solusi Sistem Untuk Mendukung Keputusan Penilaian Kinerja Dosen Menggunakan Metode Analytical Hierarchy Process (AHP). In Prosiding Seminar Nasional Riset Information Science (SENARIS) (Vol. 1, pp. 142-149).

Suharsaputra, U. (2010). Manajemen Sumber Daya Manusia Pendidikan.

Sujana, P. (1997). DNA fingerprinting in some mulberry (Morus spp.) genotypes (Doctoral dissertation, M. Sc. dissertation, University of Mysore). 